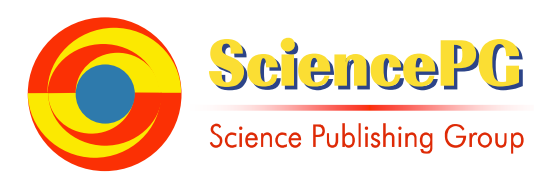

\title{
Entrepreneurial Philanthropy Meet with Non-Profits - In Search for Alignment
}

\author{
Jos Rath*, Theo Schuyt \\ Faculty of Social Sciences, VU University, Amsterdam, The Netherlands
}

Email address:

j.rath@rathgroup.com (Jos Rath)

\section{To cite this article:}

Jos Rath, Theo Schuyt. Entrepreneurial Philanthropy Meet with Non-profits. International Journal of Economic Behavior and Organization. Vol. 3, No. 4, 2015, pp. 55-64. doi: 10.11648/j.ijebo.20150304.11

\begin{abstract}
Entrepreneurial philanthropy is becoming more significant in the domain of social change, yet an understanding of how non-profit organisations respond to the phenomenon, and vice versa, has received minimal academic research outside the United States. However, charitable giving with a venture bent may be an uncomfortable realm and can impose a culture shock for non-profits. Also the organisational processes of non-profits can be equally as uncomfortable for entrepreneurs, which may cause potential frictions. The paper seeks theoretical considerations to determine a framework that describes the alignment paradigm, in the situation entrepreneurial philanthropy will meet up with non-profit organisations. The primary focus is to select valid domains where compelling choices for both are foreseen, along with the qualifying variables to guide the meeting process effectively. The paper proposes a conceptual approach of alignment that may offer observations for enhancing the concept of entrepreneurial philanthropy.
\end{abstract}

Keywords: Entrepreneurial Philanthropy, Non-profit Organisation, Philanthropreneur, Alignment

\section{Introduction}

In civil society, non-profit organisations currently face a number of challenges, including governments retracting financially from a large number of areas. At the same time a new generation of philanthropreneurs 1 want to respond to societal problems, and seem able to make a contribution to improve the civil society by investing in non-profits, by using their capital, expertise and network assets [1]. The returns envisioned are partly financial, partly societal and partly symbolic, which fit within the current zeitgeist, which proposes that some entrepreneurs seek impact creation as an alternative to unfettered economic growth. Non-profit organisations want to respond to these shifting powers in civil society, but do not always feel familiar with these alternative forms of financing. Consequently, this unfamiliarity may lead to a Tower of Babel speech confusion when they meet with one another, which may result in nonprofit organisations having to seek alternate sources of

1 The term 'philanthropreneur' dates back to a publication entitled The Philanthropreneur Newsletter that existed in 1997. However the term is claimed to be coined by Internet entrepreneur Mark Desvaux in 2004 to describe "billionaires who have reaped the benefits of capitalism, and believe that it can be applied in the service of charity". fundraising, or suspending or cancelling of projects [2]. However, the envisioned partnership determines the premise upon which the theoretical framework proposed in this paper is based, and provides the conceptual volition to analyze the implicit ways entrepreneurial philanthropy can be made a rewarding endeavor. Based on actual management insights, possible alignment criteria are determined, including areas of potential friction of their competencies [3]. The bias in decisions non-profit organisations make regarding entrepreneurial philanthropy due to their organisational models to provide effective responses, and the business values of philanthropreneurs, are unexplored areas requiring further research.

\section{Shifting Powers in Civil Society}

The existence of civil society organisations might prove to be a necessity rather than a luxury, and since the 20th century have persuasively been prompted by the inadequacies of the welfare state and the market to create participatory and sustainable societies. Viewed at a more global level, these inadequacies seem to have evolved significantly over the last two decades, where technology, geopolitics, and markets have been stimulating the constitution of civil society, giving rise to models for citizen expression, and the involvement in 
governance processes to help address a wide variety of social needs. Although there is no framing formula that consistently boosts power, civil society cannot survive without the market and the market requires civil society for its growth [4]. Civil society today can be recognized as a 'bewildering variety of interacting habitats and species, such as non-profit organisations, non-governmental organisations, voluntary groups, civic initiatives, social movements, protest organisations, whole nations, ethnic and linguistic clusters, pyramids, and networks' [5]. Information and communication technologies enables new combinations of actors, leading to a powerful growth of civil society activity, and enabling (online) networks to be built across geographical, social and physical divides. These networks allow greater numbers of people to aggregate and collectively address societal challenges [6].

The changes civil society is undergoing suggest that it should no longer be viewed as the 'third sector'. Many western countries enjoy the high standard of living they currently experience because citizen generosity (philanthropy) and citizen engagement (non-profit organisations) created an environment in which business could flourish without destroying the social fabric of society [7]. The civil society appears to be more the glue that binds public and private activities together in such a way that strengthens social capital, in what can be seen as an unsubstantiated informal norm that promotes cooperation between individuals. In the economic sphere, these relationships between public and private organisations reduces transaction costs, and in the political sphere it promotes the kind of associational life necessary for the success of limited government and modern democracy [8]. In playing this role, civil society actors ensure they retain their core missions of integrity, purposefulness and high levels of trust. Achievement in such complicated and dynamic settings depends on leaders who can exploit opportunities in the particular structure of power relations. It is likely the need for independent organisations and individuals to act as an 'ethical Cerberus' or 'watchdog of the excluded' will persist into the future, and a vibrant and independent civil society might be an essential ingredient of an effective and stable democracy. Civil society groups are often considered to be more trusted than governments or business, and may also discover new ways of improving societies across the world, as the power of civil society takes many forms.

The steady depletion of social capital in society provides a major challenge, as the market cannot provide this public good alone. Putnam advises that 'building social capital will not be easy, but it is the key to making democracy work' [9]. Sources of social capital are currently changing in an increasingly global, networked, and multi-stakeholder world. Within the complex civil society some actors, such as social media communities and networks, appear to have developed an enhanced role. Recognizing that not one sector can solve the world's major societal challenges alone, these roles are increasingly carried out through engagement in partnerships and collaborative frameworks across civil society. As well as the traditional stakeholders from government and international organisations, a growing interest from entrepreneurial philanthropy can be observed.

To have an effective framework, the Pestoff welfare triangle [10] is utilized, and provides a delimited overview of the spheres of action within the welfare state (Figure 1). The three determent sectors of the model comprise community, state, and market. Each sector has its sources and motives, and its principles and leading actors. The division within the triangle indicates the distinction between public and private sector, between for-profit and non-profit work and between formally and informally organized societies. Pestoff suggests that the central sector of the triangle, is reserved for the civil society and can express degrees of privateness or publicness, non-profitness or for-profitness and formality or informality, placing them closer to one of the other three sectors.

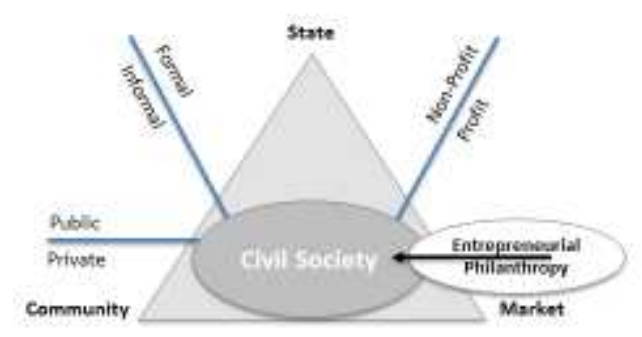

Figure 1. Pestoff's Welfare Triangle enlarged by Entrepreneurial Philanthropy.

Pestoff's triangle provides direction to define governance institutions in society, as well as to depict the change in the welfare mix in post-industrial societies [11]. The unique concept of civil society as 'the space where we act for the common good' is expanding, as civil society actors more frequently play the role of enabler, in developing partnerships with other stakeholders. In post-industrial societies in which people live both better and longer lives, neither the market nor the state can fulfil all the needs of its citizens [12]. There are a variety of reasons for this, including what can be recognized as market failure and government failure. However, voluntary failure may also be a factor. Consequently, dissatisfaction with the achievements of non-profits and their relationship to donors has provided the impetus for the development of alternative methods of fundraising [13]. Given the philanthropreneurs' ambition to resolve 'wicked problems' in society, entrepreneurial philanthropy is currently entering the central sector in the Pest off triangle, indicating a possible enlargement of resources. Unlike charitable giving, entrepreneurial philanthropy seek to tackle the root causes of societal problems by applying tailored financing methods to identify and deliver solutions to challenging social and economic problems, rather than making charitable donations to alleviate the inequalities created by these problems [14]. Civil society, in a metaphor, is an engine of world society, and from a philanthropic standpoint it complements states, communities and markets which have their own distinct tasks and shape. The scope and ambition 
of entrepreneurial philanthropy has tempted observers like Chandler to discuss of a possible 'power shift' in the global civil society by the actions of 'norm entrepreneurs'[15]. The current paper explores what theoretical frame works may be used to develop an alignment between a non-profit organisation and philanthropreneur, to address societal problems, and describes the two partners within their natural habitus.

\section{Characteristics of Non-profit Organizations}

The concept of a non-profit organisation can be understood through a comparison with the for-profit business. The fundamental distinction between the two is that the business operates for the economic benefit of its owners, while the non-profit is not permitted to distribute its profits [16]. In order to survive, non-profits, just like businesses, ensure that the organization's revenues exceed its expenses. However, this model should not be confused with the term 'not-for-profit'. The former describes a form of organisation, and the latter a type of activity. The term 'non-profit' refers to the fact that the sole aim of these organisations is to provide services either for free or at a nominal cost, and to not earn financial profit, which is different from either business or government. Within the scope of the paper, a non-profit is defined as a charity, and refers to an fundraising organisation that operates to fulfil purposes that may benefit society such as religion, healthcare, international aid, environment or nature, education, culture, sports, and societal. Non-profits can vary enormously, like business, in terms of mission, size, mode of operation, and impact. Whilst some non-profits are closer to a model of a government agency, others may resemble a corporation, and others may be little more than an informal network[17]. Non-profits pursue public benefit purposes that are recognized to the welfare of the society, and generally have the core characteristics listed in Figure 2[18].

Figure 2. Core characteristics of non-profit organisations (Salamon \& Anheier, 1997).

\begin{tabular}{|c|c|}
\hline Organisation & $\begin{array}{l}\text { Possessing some institutional reality, which separates } \\
\text { the organisation from informal entities such as families, } \\
\text { gatherings or movements }\end{array}$ \\
\hline Private & $\begin{array}{l}\text { Institutionally separate from government, which sets } \\
\text { the entity apart from the public sector }\end{array}$ \\
\hline $\begin{array}{l}\text { Non-profit } \\
\text { distributing }\end{array}$ & $\begin{array}{l}\text { Not returning any of the profits generated to owners or } \\
\text { equivalents, which distinguishes non-profits from } \\
\text { businesses }\end{array}$ \\
\hline Self-governing & $\begin{array}{l}\text { Equipped to control their own activities which } \\
\text { identifies those that are de } \\
\text { jure units of other organisations }\end{array}$ \\
\hline Voluntary & $\begin{array}{l}\text { Being non-compulsory in nature and with some degree } \\
\text { of voluntary input in } \\
\text { either the agency's activities or management }\end{array}$ \\
\hline
\end{tabular}

Non-profit organisations, which tend to having multiple bottom lines that enable the means to provide their service and not profit as a goal, seem more complex than businesses.
Although both non-profits and businesses engage in planning, budgeting, accounting, and marketing, contend with arguments of governance, personnel and information management, and must raise money occasionally, these activities are carried out in markedly different ways [17]. There seem no natural price mechanisms that might accumulate the consequence of clients, management, volunteers or other stakeholders that can match costs to profits, supply to demand and goals to actual achievements. Unlike the management issues in the for-profit sector, which tend to be clear and correspond to specific economic measures, issues in non-profits are more ambiguous because they are related to the somewhat abstract public services. The challenge for non-profit management lies in developing new models that identify these abstract components, their cultures, goals and operating procedures in an effort to establish coherence between mission, activities and outcomes [19]. However, non-profit management has much to offer in this process, because they may see conditions in significantly different ways, such as mobilising teams through more democratic structures. For example, using reflective and contemplative practices to improve their performance, developing accountability mechanisms that bring in all their stakeholders, and finding innovative ways of measuring their impact on both short- and long-term goals [20]. Non-profits typically start with defining their mission and then activate their human and financial resources for achieving their goals [21].

The sources of revenue for non-profits vary, some are supported by donations or grants and generate income from investments, other also receive financial assistance from governments, and in some cases others also generate income from the sales of their own products or services. Since securing funding is no easy task, non-profits tend to be more revenue conscious in comparison with business enterprises. Non-profits fear for their resources because it is difficult to fundraise and there is the impression of a financial deficit. In contrast to businesses, non-profit organizations typically do not base their strategy on revenue, nor do they make revenue the center of their plans. A typical consequence of such capital behavior is the 'state orientation' of non-profit organisations, which is particularly present in continental Europe. The governance of non-profits tend to range from the autocracy of sole trustees selected from among the descendants of charitable donors, through to broadly representative boards composed of elected officials or directors elected by members of the organisation [22].

Governance, organisational accountability, financial reporting, and planning are contrasting in non-profit organisations, whose special defining characteristics are legally constituted as non-governmental entities. While all non-profits must operate with solid financial discipline, it is not financial acumen and discipline alone that make for a consistently good performance. Rather, success is a function of infusing financial perspectives with field-based experience in the social aspects of the market in which the fund operates, including its diverse beneficiaries, non-profit infrastructure, 
and policy environment. What seems to constitute a good or a bad performer is not whether it is a non-profit or a business enterprise, but whether there is a clear focus to work, with strong learning and accountability mechanisms that keep the organisation heading in the right direction, and the ability to motivate volunteers or staff to reach the highest collective levels of performance. However, the terminology used by a non-profit might confuse the philanthropreneur about their abilities, capabilities and limitations and therefore a better insight into the characteristics of entrepreneurial philanthropy can help develop a better understanding of partnerships.

\section{Characteristics of Entrepreneurial Philanthropy}

The economic and financial crisis of 2008 has accentuated the social, cultural and economic dislocation experienced by disadvantaged communities at a time of unprecedented political and public interest in philanthropy. The crisis may have also increased the social impact economy, which is comprised of voluntary organisations, social enterprises, impact investors, B-corps, coops, etc. In post-industrial societies, in which people live both better and longer lives, neither the market nor the state can fulfil all the needs of its citizens [12]. This has concentrated attention on the contribution that philanthropreneurs might make in addressing socio-economic challenges, and on the role that innovation can play in regenerating communities. Philanthropy is traditionally seen as a "voluntary and unconditional redistribution of wealth, by the private sector"'[23]. It has been argued there is a natural connection between entrepreneurs and philanthropy, and the level of contributions given depends on the frequency and intensity of participation, volunteering, and being asked to contribute [24]. Entrepreneurial philanthropy however, is not about the unconditional redistribution of wealth or about supporting the most effective and trustworthy non-profit. Rather, entrepreneurial philanthropy is a mind-set that constantly seeks opportunities to build lasting impact out of informed understanding. To disrupt the status quo, drive philanthropy at scale, and develop long-term economic vitality through investing, the same models for success in business are applied to philanthropic endeavors [25].

There is a positive correlation between fulfilling peoples' needs as an entrepreneur and as a philanthropist [26]. Their motivations to support a non-profit can be affected by internal or external sources, and therefore the balance can vary, depending on existing barriers and motivators. Internal sources are primarily ideological and can have a negative or positive effect on giving behavior[27]. External sources include the dynamics of various social groups, experiences from the interaction of these groups, social and political processes, economic changes and philanthropic messages[28]. Entrepreneurs are motivated to engage with philanthropy at time when they felt secure in their business endeavor [29].
By voluntarily 'giving back' to the civil society, philanthropreneurs can demonstrate that societal inequality is a temporary manifestation, and through which charitable spending, can deliver public benefit.

Motivations of philanthropic actions are comprised of theoretical constructs such as immortality striving, legacy creation, and generatively [30].Furthermore there are variables that moderate these relationships, including the entrepreneur's age, gender, and sufficient economic capital required to implement a sustainable business model [14]. The third factor, or the constitutive, is symbolic capital, which is acquired through recognition, prestige and reputation may play a crucial role. A donor may be motivated to act philanthropically because of the personal recognition he or she receives [31]. In addition, to stand out from the crowd, and to be a distinguished figure it is necessary to transcend self-interest and promote causes with apparent selflessness [32]. Holders of symbolic capital are able to influence and control the thoughts and behaviors of others and in turn facilitate change outside the normal conventions of decisionmaking [33]. These values of approval have a strong effect on giving, and may easily overpower effects by other mechanisms [34].

Because entrepreneurship is associated with the creation of new business ventures and innovations in the for-profit economy, entrepreneurial philanthropy can be distinguished as a contradiction in terms. The philanthropreneurs have the appearance of deriving satisfaction from providing some charitable output or fulfilling a social mission rather than from simply pursuing profit as a means of increasing their income. They are feasibly utility maximisers rather than profit maximisers. Moreover, although decisions about nonprofit entry and exit are more usefully modelled as being motivated by utility rather than by profit, many factors such as changes in demand, the presence of incumbent providers, and financing constraints, play similar roles in explaining broad patterns of entry and exit in the case of non-profit organisations as they do in models of entry and exit by forprofit businesses [35].

Figure 3. Exploratory definition of entrepreneurial philanthropy (Rath \& Schuyt, 2014).

\begin{tabular}{|c|c|}
\hline $\begin{array}{l}\text { Mission } \\
\text { Vision } \\
\text { Investment } \\
\text { Return }\end{array}$ & $\begin{array}{l}\text { The search of entrepreneurs to solve societal problems, } \\
\text { by increasing the measured philanthropic impact of } \\
\text { connected non-profit organisations, } \\
\text { through a tailored investment of their economic assets, } \\
\text { acquiring(symbolic) capital, on a not-for-profit basis. }\end{array}$ \\
\hline
\end{tabular}

The formulated exploratory definition described in Figure 3 [36] identifies and explains antecedents to entrepreneurial philanthropy and is a critical concept in understanding the behavior that incorporates the ambition to drive societal change. The ideological business commitments of entrepreneurs and their motives come together in entrepreneurial philanthropy to support non-profit organisations, and this explanation provides an improved understanding and can be compelling for non-profit organisations if they decide to become more market-like in 
their actions, structures, and philosophies.

When considering the definition proposed by Rath and Schuyt, the question arises as to whether the world of entrepreneurial philanthropy is intrinsically associated with distinctive features that lead to characteristic behaviors and outcomes when it meets the world of the non-profit organisations to solve a societal problem.

\section{When Two Different Worlds Meet}

The traditional mix of organisational and strategic objectives may challenge both non-profits and entrepreneurial philanthropy grounded priorities when they want to engage. Non-profit organisations appear different from entrepreneurial philanthropy because of their multiple funding streams and the fact that they may carry unique commitments in civil society [37]. Non-profits are dedicated to 'doing good' and have a clear mission that drives everything the organisation does. However, the upward trend of bringing about beneficial social impact among philanthropreneurs is matched by a comparable, converse trend among non-profits, which Grit refers to as "the economisation of non-profit organisations" [38]. Grit demonstrates that striking changes have taken place within non-profit organisations since the $1980 \mathrm{~s}$, which can be encompassed by the denominator of 'economisation'. For example, business practices are brought to scale and the overhead ratio is denounced as a valid indicator of their performance [39]. Starting with their mission, and its requirements, non-profits may define specific strategies needed to attain societal goals [40]. Conversely, non-profits generally do not base their strategies on money. Terms such as accountability, return on investments, relationships, and even the definition of target group often have different meanings for non-profits. It may subsequently be the case that entrepreneurial philanthropy drives non-profits, or vice versa, to adjust behavior to embody the new relationship which is prioritized to create societal values as well as corporate values. However, the claim that business thinking will save the world can be a convenient myth for those who occupy positions of wealth and power, and is a dangerous distraction from the public work of finding solutions [41]. It appears as if challenging for non-profits to communicate effectively about their business-worthiness and what they can offer to philanthropreneurs in return [42].

Processes in which non-profits use grants and donations as their main funding tools and the philanthropreneur intends to allocate tailored investments, the general assumption is that the magnitude of the investment will not affect the donation behavior of other (existing) sources of funds. This assumption is potentially incorrect. In the case of multiple financiers, conflicting criteria could result in escalating tensions, as well as disordered objectives and increased overhead costs. For that reason, financial diversification is a two-edged sword, and the pros and cons of alternative fundraising sources must be carefully considered before a decision can be reached on whether or not the funding source should be accepted [43]. The more philanthropreneurs experience a personal attraction to strong, independent initiatives, the more they will be reluctant to invest [44]. Therefore, when attempting to raise the value created through an investment of financial assets, an investment strategy is required. The strategy view grant making, asset investment, and the use of low-interest loans as three integral parts of a holistic approach to applying, and maximizing the impact of the foundation capital resources[45].In addition compiling a finance portfolio can provide insight into how much time and energy is spent on each source of funding, what the relationships are between them, how they affect one another and what the conditional impact is [46].

Generally, for non-profits, the question of 'what do we want to achieve and what is our strategy to achieve these goals?' is quite complex to answer. The outcome is referred to in terms of impact, a term that is given various meanings by non-profits and their financiers. Maas' definition of impact is "impact is the effect organisations have on society, on the economic, environmental and social dimension of society", which indicates that impact can be defined as the societal value created by non-profits [47]. This societal value can manifest itself in various dimensions such as socially, economically, environmentally and on various levels such as the individual and the organisation, the environment and the social system. Research about what impact, as distinct from output and outcomes, has upon society, is becoming more prominent. The measured output and outcomes, however, are in no way static and occasionally the numbers show a different reality than previously imagined, and unforeseen side effects occur that contribute to resolving the issue at reach [48]. Business structures are not likely to easily facilitate these slow, community based processes that many think are needed to effect true social change. It can be argued that the reason change is needed because tight structures are not allowing these processes to happen. Evaluating the philanthropreneur's demand for impact measurement, requires non-profits to adopt a fundamentally different working style in which the value judgments are shifted from intentions to results. As yet, this focus seems to have a negative effect on the disposition of non-profits towards the impact concept and accounting for it [41].

Business ethics are key in determining the moral climate of the envisioned partnership between a non-profit and a philanthropreneur, and the scope of the partnership, from an individual level to that of society, from the interaction between individual employees to the organization's social responsibility in regards to of issues such as the environment, and the allocation economic resources and human resources. If ethics in a general sense reflects the way people ought to behave regarding certain circumstances, then organisational ethics reflect the way organisations ought to behave [49].In contrast to businesses, non-profits generally lack a formal policies convey the impression of having difficulty in making clear decisions, and do not recognize that some situations raises ethical issues [50].

The recent economic downturn has shown that good 
governance is not a frivolous luxury. In many business failures, the board was the last to realize the economics were going wrong. Non-profits generally have the advantage of a professional board that annually review the performance of the management, and also review themselves against a preset performance objectives. In the Netherlands, the Governance Code for Charities, or Code Wijffels [51], defines several basic principles of good governance for nonprofit organisations, including a stipulation that indicates supervisory authorities are accountable for "the risk management facilities in place at the institution and the operation of such facilities". To properly inform philanthropreneurs, non-profit organisations are required to implement a system of management control and compliance [52]. The external supervisory authorities are the custodians of maintaining continuity and see to it that the organisation actually carries out all of its projects. In addition the business practices of non-profits must be coherent and honorable in all ways [53]. Philanthropreneurs expect transparent insight of their investment to ensure their funds are used for the intended objective and that certain guarantees are in place. Continuous attention to good governance and transparency contributes to engendering trust that all checks are carried out [54].

The recognized differences may affect the way a nonprofit organisation and entrepreneurial philanthropy reach a partnership in order to present relevance and legitimacy for the stakeholders each entity is responsible to. When conducting an entrepreneurial approach within non-profits, it is crucial that the situation does not escalate into confusion. A common source of confusion is that entrepreneurial philanthropy is often a question of terminology. The question arises as to what theoretical framework can be developed through exploratory research, to deliver an effective insight into the development of an alignment between a non-profit and a philanthropreneur, with mutual benefits.

\section{Exploring Alignment}

The entrepreneurial approach illustrates the encroachment of an opposing ideology and set of practices that might threaten the non-profit sector's unique role in society [55]. Non-profits are viewed as an evolving societal system, encountering challenges that frequently involves fundamental dilemmas for management and staff. Multiplicity seems to be the signature of the partnership between the non-profit and the philanthropreneur when they interact with each other over time, and deal with the opportunities and constraints as part of a larger economy. Entrepreneurial philanthropy does not have the appearance of a linear process, but is rather iterative in nature and requires the consideration of multiple variables, which increases the disquiet felt when having to address the challenges involved. The challenge lies in exploring theoretical considerations for a framework that identifies the discriminant characteristics of the domains leadership, strategy and culture, in an effort to establish coherence and identity between mission and outcomes [56]. It is therefore necessary to understand what is required to find the balance between achieving outcomes and impact with the need to embrace corporate, social and political dynamics.

The three domains outlined in the 'Theoretical Framework of Alignment' (Exhibit 4) are indicating characteristics and variables that can describe the development of a partnership over time. Alignment is defined here as: 'the best possible adoption of entrepreneurial philanthropy by a non-profit organisation, to effectively realize a measurable improvement of their societal objective'. The hypothesis proposes that alignment implies a potential for growth towards an optimal maturity of the partnership. Alignment may also express the richness of the non-profit process, to apply entrepreneurial philanthropy projects effective throughout the organisation. The impetus might cause an adjustment of alignment in relation to each other, and consequently arrangements can lead to a better understanding of what can increase the performance results of the envisioned societal impact. It requires forethought and taking proactive actions where the management performance to the strategic direction requires leadership and monitoring. To coordinate different functions and resources, diplomatic handling of personalities across the organizations pretends of influence. When the alignment criteria in the identifying characteristics attributes, organisation, and communication, are adjusted within the philanthropic strategy, a high degree of organisation readiness can arise [57]. Therefore this situation has the ability to mobilize and sustain the change processes required to execute an entrepreneurial impact strategy.

Based on the domains of leadership, strategy, and culture, there are five characteristics outlined the Theoretical Framework of Alignment (Figure 4). Within these characteristics and their variables, choices are foreseen that may affect a partnership, and are as follows:

Characteristic: Attributes

The personal background and behavior of the philanthropreneur and director/chairman involved. What drives them to accomplish societal change and what makes them interested to partner.

\section{Characteristic: Metrics}

An understanding and acceptance of the competency and value measurements that demonstrate the contribution of the philanthropreneur and director/chairman involved.

Characteristic: Governance

Governance is used to describe the policies, organisational structures, and procedures, which operate the organisational structure, and internal relationships.

Characteristic: Organisation

Including management style, performance feedback, and encouraging innovation, as well as the readiness for change, capability for learning, and ability to leverage new ideas.

Characteristic: Communication

The exchange of ideas, knowledge, and information 
among the partners, enabling both to have a clear understanding of strategies, and what must be done to achieve them.

Each of the five characteristics focusses on variables based on the determinants that drive the concept of entrepreneurial philanthropy [36], and are validated with an evaluation of the Parmenter Index of Key Performance Indicators [58].

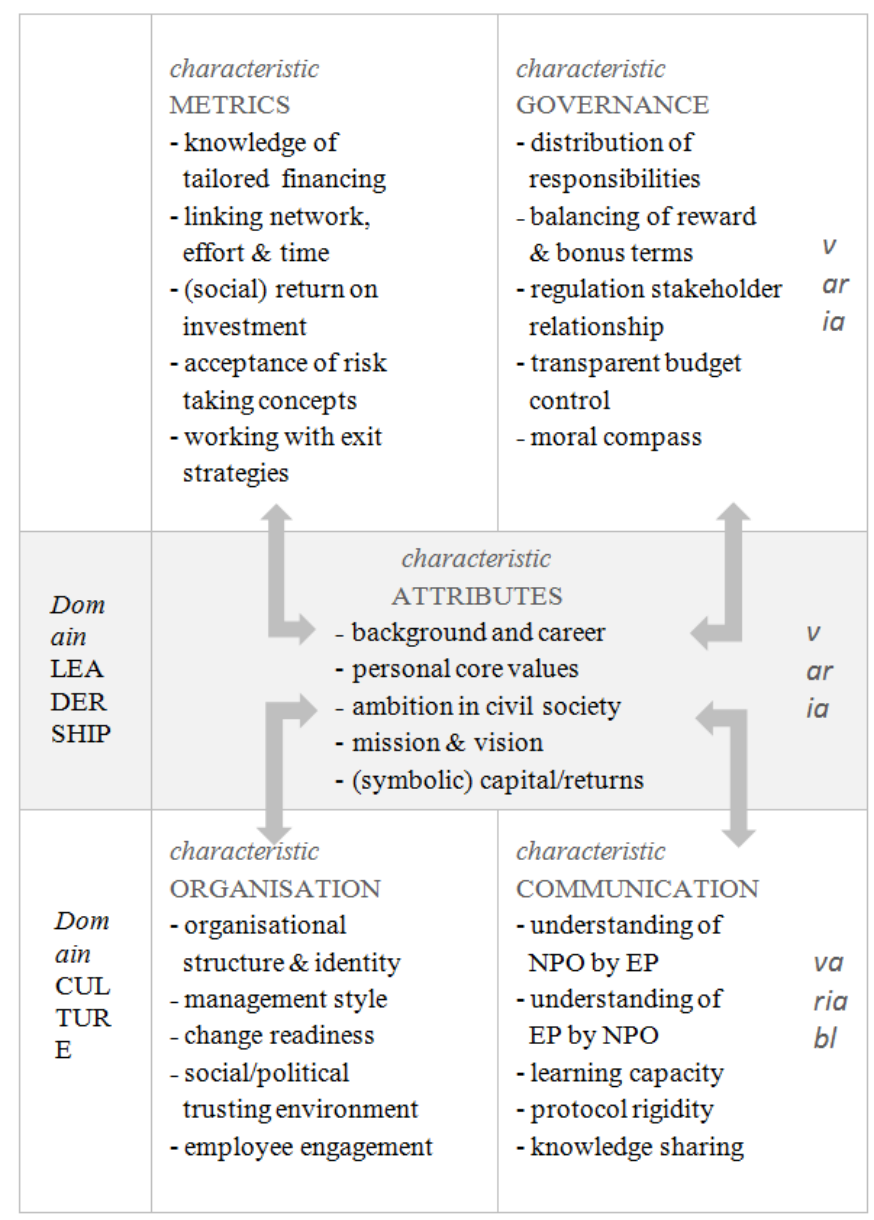

Figure 4. Theoretical framework of entrepreneurial philanthropy alignment.

Two exploratory research approaches foreseen in the theoretical framework, help to distinguish the ways nonprofit organisations can benefit from the entrepreneurial source [3]. Firstly, the philanthropreneur is the driver for the tailored financing strategy, and the non-profit determines what infrastructure and processes will be needed for implementation. Differences may arise in the various levels of alignment, in order for both to achieve a shared understanding of how strategy setting becomes implemented as architecture and as process. The challenge of the philanthropreneur is to balance the different, and often contradictory elements that form the component parts of nonprofit organisations. In the second research approach, the non-profit drives the fundraising strategy, determining beforehand what infrastructure and processes are required for implementation. The management of the non-profit has the option to consult with the philanthropreneur, and together they can identify the appropriate anchor characteristic (the strongest characteristic, in which strategic choices are most often made), and swivel characteristic (the weakest characteristic) for their philanthropic model. This consultation can facilitate understanding in regards to both the appropriate roles each other plays, and how changes in leadership, strategy and culture are expected to be made [59].

The two research approaches represent a mutual and continuous process, and are not considered goals but ways to determine guidelines to take the strategic alignment to a higher level. In the perspective of the theoretical framework, it is interesting to investigate which set of interventions might lead to maturity of the partnership. The following determinants can be distinguished:

- Non-profit organisations are dependent on the success of their fundraising strategy, what ultimately determine their desired impact;

- The fundraising strategy of non-profits is dependent on external financiers, for example the philanthropreneur;

- The tailored financing strategy (money, network, effort and time) of the philanthropreneur will depend on the interaction with and acceptance of the director/chairman of the non-profit;

- The fundraising and financing options are connected with each other, and are a basis of power;

- Power seems relational, reciprocal, and evidential;

- Independent organisations keep each other's strategies in balance;

- Potential differences reveal themselves both in leadership and culture.

In traditional business alignments, the problem is often not what happened in reality but the perceptions and feelings of each individual in the proposed partnership. The primary aspects of alignment maturity appears related to attributes of commitment, coordination, and trust, communication quality and participation, and the conflict resolution technique of joint problem solving [60]. An analysis of variables, such as: personal values, organisational values, operating governance, and stakeholders pursuit could be beneficial. It allows the planning to take a macro-look at the partnership to integrate assessment into the process, and to detect severe implementation and functionality problems, if not outright failure [21]. In addition, if one of the partners believes his or her values have been neglected, he or she is unlikely to implement the plan into daily work procedures and consequently the benefits are not obtained. When the alignment is deployed correctly, it can simultaneously leverage individual advances and team effectiveness toward the aspirations of both partners [61].

The defined theoretical framework will be further investigated in qualitative research among the management of non-profits and philanthropreneurs in the Netherlands, to learn more about their contribution to reach a mature alignment. The potential frictions, once determined, will describe the interrelationships between the variables of the theoretical framework and their possible effects on the behavior of the parties involved. Additionally an argument should be formed as to whether alignment occurs when the 
selected relations as defined, and are in balance. Evolving resource dependence by non-profit management might be demonstrated by the shifting reliance to the new sources of tailored finance from entrepreneurial philanthropy. It is assumed that the alignment process comprises the variables emerging from social exchanges, and are formed to influence attitude and to control behavior. The framework described in this paper incorporates theories of human motivation, and therefore provides an explanation of the mechanism by which humans may desire constant change [62]. There seems enough to be gained from the theoretical framework of alignment, to consider how the observations will enrich an understanding of the phenomenon.

\section{Conclusion and Discussion}

In the 21 st century, philanthropreneurs do realize they are not operating independently. Like their businesses, they certainly cannot ignore the concerns of their shareholders, and in their philanthropic work they also cannot ignore the concerns of other stakeholders, including a powerful civil society. Philanthropic work and businesses can be complementary, as many non-profits prove, often using business metrics to assess performance and effectiveness [63] While the fundamental goals of non-profits and entrepreneurial philanthropy may differ, the ways in which societal problems can be solved remain the same, for example through a clear mission, good management, a strong team, hard work and dedication [64]. In addition, a dynamic process that ensures a philanthropic alignment, both in organisational and in financial strategy, is required. The two approaches have similar goals and objectives for the civil society. There has been limited research in the area of entrepreneurial philanthropy, in particular the differences between the philanthropreneur, who gain some 'warm glow' from charity, and the non-profit organisation itself. When moving into an unknowable future partnership, it is critical for both entities to understand whether the knowledge and attitude of the philanthropreneur makes it possible to understand the behavior of non-profit organisations, and vice versa.

If entrepreneurial philanthropy is to succeed, it will likely be due to philanthropreneurs taking societal impact seriously and applying their business talents just as rigorously as they did when they made their wealth. However, the difficulty appears to be that non-profits lacks many of the market forces that keep philanthropreneurs disciplined, focused on success, and willing to make the tough decisions necessary to survive and prosper [14]. As it is yet unknown to what extent the various effects of the partnership may cause sources of friction when the two worlds meet. Language differences might reflect identity differences that can challenge the partnership if each assume they are using terminology in the same ways, and therefore it is crucial that those involved learn to understand each other's language. Testing the theoretical framework of alignment may offer a better understanding of the key drivers of a mutually profitable partnership.

\section{References}

[1] Sluyterman, K.E. (2012). Corporate Social Responsibility of Dutch entrepreneurs in the $20^{\text {th }}$ century. Enterprise \& Society, 13(2), 313-349.

[2] Moody, M. (2008). Building a Culture: The Construction and Evolution of Venture Philanthropy as a New Organizational Field. Non Profit and Voluntary Sector Quarterly,37(2), 324352 .

[3] Gray, D.E. (2004).Doing Research in the Real World. London: Sage Publications.

[4] Edwards, M. (2009). Civil Society. Cambridge: Polity Press.

[5] Keane, J. (2003). Global Civil Society? Cambridge: Cambridge University Press.

[6] Firmin, A., Pegus, C-M., \& Tomlinson, B. (Eds.) (2014). The State of Civil Society 2013: Creating an enabling environment. Johnnesburg: Civicus.

[7] Gaudiani, C. (2010). Generosity Unbound. New York: Broadway Publications.

[8] Fukuyama, F.(2001).Social capital, civil society and development. Third World Quarterly, 22(1), 7-20.

[9] Putnam, R.D., Leonardi, R., \& Nanetti, R.Y. (1993). Making Democracy Work: Civic Traditions in Modern Italy. Princeton: Princeton University Press.

[10] Pestoff, V.A. (1992). Third sector and co-operative services. From determination to privatization. Journal of Consumer Policy, 15(1), 21-45.

[11] Van der Meer, T., Te Grotenhuis, M., Scheelers, P. (2009). Three Types of Voluntary Associations in Comparative Perspective: The Importance of Studying Associational Involvement through a Typology of Associations in 21 European Countries. Journal of Civil Society, 5(3), 227-247.

[12] Schuyt, T.N.M. (2001). Het geven van geld. In: Burger, A. \& Dekker, P. (red.) Noch markt noch staat, de Nederlandse nonprofitsector in vergelijkend perspectief. Den Haag: Sociaal en Cultureel Planbureau, 139-151.

[13] Porter, M.E. \& Kramer, M.R. (1999). Philanthropy's New Agenda: Creating Value. Harvard Business Review, 77(6), 121-130.

[14] Bishop, M. \& Green, M. (2008). Philanthrocapitalism: How Giving Can Save the World. New York: Bloomsbury Press.

[15] Chandler, D. (2004). Constructing Global Civil Society; Morality and Power in International Relations. Hampshire: Palgrave Macmillan.

[16] Hopkins, B.R. (2009).Starting and Managing a Nonprofit Organization: A Legal Guide. Hoboken: John Wiley \& Sons.

[17] Wolf, T. (1999).Managing a Nonprofit Organization in the Twenty-First Century. New York: Fireside.

[18] Salamon, L. M. \& Anheier, H. K. (eds.) (1997). Defining the Non-profit Sector: A Cross-National Analysis. Manchester: Manchester University Press. 
[19] Anheier, H.K. (2000).Managing non-profit organisations: Towards a new approach. London, Civil Society Working Paper series, 1. Centre for Civil Society, London School of Economics and Political Science.

[20] Edwards, M. (2008). Just Another Emperor? The Myths and Realities of Philanthrocapitalism. Demos: A Network for Ideas \& Action (US), The Young Foundation (UK).

[21] Drucker, P.F. (1990).Managing the Non-profit Organization; Principles and Practices. New York: HarperCollins Publishers.

[22] Mitchell, G.E. (2013).The Construct of Organizational Effectiveness; Perspectives From Leaders of International Nonprofits in the United States. Nonprofit and Voluntary Sector Quarterly, 42(2),324-345.

[23] Acs, Z.J., \& Dana, L.P. (2001). Contrasting Two Models of Wealth Distribution. Small Business Economics 16, 63-74.

[24] Baumol, W.J. \& Strom, R.J. (2014). Entrepreneurship and philanthropy: protecting the public interest. In: Handbook of Research on Entrepreneurs' Engagement in Philanthropy, Cheltenham: Edward Elgar.

[25] Gordon, J.C. (2011).Power, wealth and entrepreneurial philanthropy in the new global economy. Glasgow: University of Strathclyde.

[26] Hummels, H., Smeets, P., Bauer, R. \& Rontgen, M.A. (2014). Van vermogen naar verandering. Amsterdam: ABNAMRO MeesPierson.

[27] Schuyt, T.N.M. (2013). Philanthropy and the Philanthropy Sector. An Introduction. Aldershot: Ashgate Publishing Limited.

[28] Midlarsky, E. \& Kahana, E. (1994). Altruism in later life. Thousand Oaks, California: SAGE Publications.

[29] Roza, L., Vermeulen, M., Liket, K. \& Meijs, L. (2014). Contemporary European E2P: towards an understanding of European philanthrepreneurs. In: Taylor, M.L., Strom, R.J. \& Renz, D.O. (Eds.) Handbook of Research on Entrepreneurs' Engagement in Philanthropy, Cheltenham: Edward Elgar.

[30] Coombs, J. E., Shipp, A. J. \& Christensen, L. J. (2008). Entrepreneur as Change Agent: Antecedents and Moderators of Individual-Level Philanthropic Behavior. Frontiers of Entrepreneurship Research, 28(21), 1-13.

[31] Meijer, M-M., Bakker, F.G.A. de, Smit, J.H. \& Schuyt, T.N.M (2006). Corporate giving in the Netherlands 1995-2003: exploring the amounts involved and the motivations for donating. International Journal Nonprofit Voluntary Sector Marketing, 11, 13-28.

[32] Suchman, M.C. (1995). Managing legitimacy: Strategic and institutional approaches. Academy of Management Review, 20(3), 571-610.

[33] Bourdieu, P. (1986). The forms of capital. In: J.G. Richardson (Ed.) Handbook of Theory and Research for the Sociology of Education, pp 241-258. New York: Greenwood Press.

[34] Bekkers, R., \& Wiepking, P. (2011). A Literature Review of Empirical Studies of Philanthropy: Eight Mechanisms That Drive Charitable Giving. Nonprofit and Voluntary Sector Quarterly, 40(5), 924-973.

[35] Austin, J.E. (2000). The collaboration challenge: How nonprofits and business succeed through strategic alliances. San Francisco: Jossey-Bass Publishers.
[36] Rath, J.H. \& Schuyt, T.N.M. (2014) Entrepreneurial Philanthropy; an exploratory review. The Journal of Wealth Management, 17(3), 35-46.

[37] Salamon, L.M.\& Anheier, H. (1998). The emerging sector revisited. Baltimore: Johns Hopkins University.

[38] Grit, K. (2000). Economisering van non-profitorganisaties: Een vertoogperspectief op de dynamiek van instituties. Beleidswetenschap, 14(1), 29-51.

[39] Pallotta, D. (2013). The way we think about charity is deadly wrong. TED Talk. http://www.youtube.com/watch? $v=b f A z i 6 D 5 F p M$

[40] Drucker, P.F. (1989). What Business Can Learn from Nonprofits. Harvard Business Review, 67(4), 88-93.

[41] Edwards, M. (2011). It's Civil Society, Stupid! A Review of Small Change: Why Business Won't Save the World. Nonprofit Policy Forum, 2(1).

[42] Hayden, C. van der, \& Rijt, G. van der(2004). Societal Marketing and Philanthropy in Dutch Companies. Journal of Nonprofit \& Public Sector Marketing, 1 (12), 23-36.

[43] Froelich, K.A. (2000). New Competitors for Small Business: The For-Profit Mentality of Nonprofit Organizations. Journal of Small Business Strategy, 11(2), 92-104.

[44] Schuyt, T.N.M., Couwenberg B., \& Bekkers, R. (2013). Geven in Nederland 2013: Giften, Nalatenschappen, Sponsoring en Vrijwilligerswerk. Amsterdam: Reed Business Education.

[45] Godeke, S., \& Bauer, D. (2008). Mission-Related Investing; A Policy and Implementation Guide for Foundation Trustees. New York: Rockefeller Philanthropy Advisors.

[46] Frumkin, P.J. (2006). Strategic Giving: The Art and Science of Philanthropy. Chicago/London: University of Chicago Press.

[47] Maas, K.E.H. (2009). Corporate Social Performance: From Output Measurement to Impact Measurement.Rotterdam: Erasmus University Rotterdam.

[48] Liked, K., Maas, K.E.H., \& Klasen, M. (2011). Performance Prediction Scan. Rotterdam, Erasmus Centre for Strategic Philanthropy.

[49] Kimman, E.J.J.M. (1991). Organisatie-Ethiek. Assen: Koninklijke van Gorcum.

[50] Rhode, D.L., \&A.K. Packel, (2009).Ethics and Nonprofits. Stanford Social Innovation Review,7(3), 29-35. Retrieved September 2014, from: http://www.ssireview.org/articles/entry/ethics_and_nonprofits

[51] Wijffels H.H.F. (2005). Advies van de Commissie Code Goed Bestuur voor Goede Doelen. Amsterdam: VFI.

[52] Centraal Bureau Fondsenwerving (2014). Naar een nieuw stelsel voor toezicht en kwaliteitsverbetering voor de filantropische sector, concept.Amsterdam: CBF.

[53] Vereniging van Fondsen in Nederland (2009). Gedragscode ten behoeve van de leden van de FIN. Den Haag: FIN.

[54] Herremans, A.H.H.M., \& Mentink, E.A.M. (2009). Verslaggeving van organisaties zonder winstoogmerk: een normatief raamwerk.Deventer: Kluwer. 
[55] Eikenberry, A. M., \& Kluver, J. D. (2004). The marketization of the nonprofit sector: Civil society at risk? Public Administration Review, 64(2), 132-140.

[56] Vicere, A.A. (2010). The Real Legacy of Leadership: Aligning Rhetoric with Reality. In: Goldsmith, M., Baldoni, J., \& McArthur, S. (Eds.). The Handbook of Leadership. New York: AMA.

[57] Kaplan, R.S. \& Norton, D.P (2004). The strategy map: guide to aligning intangible assets. Strategy \& Leadership, 32(5), $10-17$.

[58] Parmenter, D. (2010). Key Performance Indicators: Developing, Implementing, and Using Winning KPIs. Hoboken: John Wiley \& Sons.

[59] Young, D.R. (2002).The Influence of Business on Nonprofit Organizations and the Complexity of Nonprofit Accountability Looking Inside as Well as Outside. The American Review of Public Administration, 32(1), 3-19.
[60] Mohr, J. \& Spekman, R. (1994). Characteristics of partnership success: Partnership attributes, communication behavior, and conflict resolution techniques. Strategic Management Journal, 15(2), 135-152.

[61] Fuda, P. (2013). Leadership Transformed: How Ordinary Managers Become Extraordinary Leaders. New York: Houghton, Mifflin, Harcourt Publishing.

[62] Froelich, K.A. (1999).Diversification of Revenue Strategies: Evolving Resource Dependence in Nonprofit Organizations. Nonprofit and Voluntary Sector Quarterly 28(3), 246-268.

[63] Day, N. E. (2004). Total Rewards Programs in Nonprofit Organizations. In: R. D. Herman \& Associates (Eds.), The Jossey-Bass Handbook of Nonprofit Leadership and Management, 2nd Edition. San Francisco: Jossey-Bass/Wiley.

[64] Sawhill, J. C., \& Williamson, D. (2001). Mission Impossible? Measuring Success in Nonprofit Organizations. Nonprofit Management and Leadership, 11(3), 371-386. 